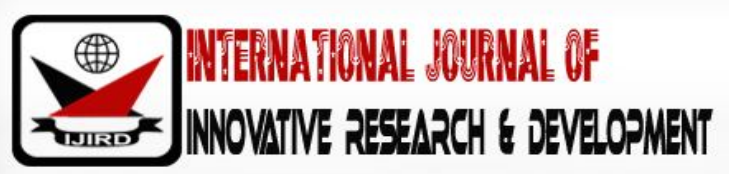

ISSN 2278 - 0211 (Online)

\section{Rangeland Degradation and Rehabilitation Efforts in the Somali National Regional State, Eastern Ethiopia: A Review}

\begin{tabular}{|c|} 
Belay Zerga \\
Center for Environmental Science, College of Natural and Computational Sciences, Addis Ababa \\
University, Ethiopia \\
Department of Natural Resources Management, College of Agriculture and Natural Resource, Wolkite \\
University, Ethiopia \\
Bikila Workineh \\
Center for Environmental Science, College of Natural and Computational Sciences, Addis Ababa \\
University, Ethiopia \\
Demel Teketay \\
Department of Crop Science and Production, Botswana University of Agriculture and Natural \\
Resources, Ethiopia \\
Muluneh Woldetsadik \\
Department of Geography and Environmental Studies, College of Social Sciences, Addis Ababa
\end{tabular}

\begin{abstract}
:
The arid and semi-arid agro-ecological area of Ethiopia cover more than $62 \%$ of the total land area. The Somali National Regional State (SNRS) occupies a large geographical area in the eastern and southeastern part of Ethiopia. The area of SNRS is estimated at $340,000 \mathrm{~km} 2$. This makes rangeland utilization by livestock, the largest land-use system in the country. The rangelands in the south of the SNRS are occupied mainly by Somali pastoralists who rear mixed herds of camels, sheep, goats and a few cattle. Rangeland degradation is the most serious challenge for pastoral livelihood in Somali Region. Major reduction in the quantity and nutritional quality of the vegetation available for grazing in the rangelands as well as expansion of localized deserts and barren areas are indicated. Major causes of degradation include climatic conditions, causing drought and arid conditions, and human factors, leading to the overuse of natural resources. Livestock density and grazing patterns lead to overgrazing, which is one of the major causes of land degradation. Overgrazing results when livestock density becomes excessive and too many animals are grazed at the same area of rangeland, leading to degradation of vegetation and the compaction and erosion of the soil. The uncontrolled browsing of trees and shrubs is another aspect of overgrazing and a patent cause of deforestation, leading to flooding and siltation in adjacent areas because rains are no longer held back by the sponge effect of the trees and carry with them large loads of eroded soil. Out of the exotic tree species Prosopis juliflora is currently spreading and encroaching the grazing lands of SNRS and is causing severe negative impacts on the production and productivity of rangelands. This species is spreading at an alarming rate into best grazing areas. Other species, such as Acacia drepanolobium, A.seyal, Lantana camara, Partheniumhysterophorus, and species of Commiphora and Opuntia are also causing serious problems by encroaching in dry and wet season grazing areas. Low and erratic rainfall is characteristic of the rangelands, and pastoral production systems have always relied upon surface and ground water sources. Strategic water development interventions have significant impact in contributing to improving range utilization. In the SNRS Birca (Cistern) and Ella (hand dug wells) are normally owned and managed by individuals. The distribution and type of water points and watering schedules are major determinants of range use. Pastoralists in SNRS have various traditional natural resource management strategies, such as mobility and utilization, herd diversity, ecosystem knowledge, local institution, fodder assessment and defined grazing, indigenous knowledge on species and their utilization. These indigenous knowledges should be kept and integrated with modern rangeland management and rehabilitation coping strategies to sustain the range ecology and the livelihood of the pastoralists.
\end{abstract}

Keywords: Rangeland degradation, rangeland management, bush encroachment, overgrazing, climate change 


\section{Introduction}

Rangelands are the large areas between deserts and agricultural zones where rainfall is generally too low or unreliable for cropping and where livestock keeping is the most important source of income (Walker and Omar, 2002). Rangelands cover about 50 to $70 \%$ of the world's landmass and provide the necessities of life for grazing and browsing animals (Holechek et al., 2001). In Africa, rangelands are the major sources of feed for ruminants and constitute about $65 \%$ of the total land area, which supports 59\% of all ruminant livestock. The rangelands of Ethiopia are mainly located within the arid and semi-arid agro-ecological zones below 1,500 m (Coppock, 1994; Mengistu, 2004). Most rangelands are caught in a spiral of desertification, land degradation and drought (DLDD), deforestation and land fragmentation (FAO,2010). DLDD has been identified as a key threat to both dryland and non-dryland communities, and sustainable economic development in drylands, particularly in developing nations (UNCCD, 2013), as they lead to reduced human well-being due to increased poverty and vulnerability of the affected dryland populations. Land degradation, in particular, has led to increased food insecurity, compromised the ecosystem integrity, and consequently lowered the quality of life of most dryland communities (Eswaran et al., 2001).

Many attempts to rehabilitate degraded rangelands have failed (Wasonga, 2011; Mureithi et al., 2014) as they placed more importance on the physicality and technicality of the interventions than the socioeconomic and cultural needs of the people (Mureithi et al., 2014). Rehabilitation of degraded rangelands through exclosuresof the commons is a successful local approach in combating land degradation in rangelands and is gaining prominence (Verdoodt et al.,2010). Exclosures refer to areas closed off from grazing for a specified duration of time in order to allow the regeneration of vegetation (Behnke, 1994; Aerts et al., 2009). Studies in Sudan (Behnke,1994; Ethiopia (Keene, 2008; Beyene, 2008; Teketay et al., 2018 and relevant references therein) and in Kenya (Makokha et al., 1999;Wasonga, 2011; Opiyo et al., 2011) all illustrate that rangeland enclosure is indeed, a well-known and successful management tool for the restoration of degraded rangelands within and beyond East Africa.

Pastoral communities usually have a detailed knowledge of their grazing lands, acquired through extensive observation and continuous herding practice (Oba and Kotile, 2001; Mapinduzi et al., 2003). Despite the existence of such knowledge, researchers and development policy experts have previously overlooked community-based knowledge when evaluating rangelands. Turner et al. (2000) concluded that traditional knowledge of indigenous people was fundamentally important in the management of local resources. Other studies (Fernandez-Gimenez, 2000; Ayana and Fekadu, 2003; Amaha, 2006; Ayana and Oba, 2008) also showed that documenting indigenous knowledge of rangeland resources can provide useful information for the development, sustainable utilization and conservation of natural resources. Additionally, community-based knowledge may provide new insights for improving existing scientific knowledge and a basis for designing appropriate research and development policies. In most parts of Ethiopia, the indigenous knowledge of pastoralists is not adequately documented (Gemedo, 2004; Amaha, 2006; Worku, 2016).

Reduction in palatable perennial grasses (Noy-Meir et al., 1989; Sarmento, 1992; Vetter et al., 2006) and an increase of unpalatable herbaceous plants due to rangeland degradation (Snyman, 2005) also play major roles in influencing foraging behavior of herbivores ('t Mannetjeet al., 1976; Hoppe, 1977; Jahnke, 1982; Snyman, 1998; 'tMannetje and Jones, 2000). Unfortunately, palatability and acceptability of fodder plants in these arid and semi-arid rangelands are poorly understood (Meissner et al., 1999; Own-Smith, 1999). Forage production of rangelands, which is influenced by climate (Behnkeet al., 1993; Swemmeret al, 2007), soil quality (Effershanket al.,1978; Snyman and du Preez, 2005) and degree of degradation (McNaughton et al., 1993; Schlesinger et al., 1990; Snyman, 2005; Abuleet al.,2007) may influence livestock production (Fourie et al., 1985; Cowling et al., 1994). The effect of rangeland degradation (decrease in palatable species and increase in soil erosion) in the arid and semi-arid rangelands of Ethiopia, and how to reverse the rate of degradation and promote sustainable use of different rangeland types have not been widely studied. As a result, grazing systems have not progressed beyond the traditional practices of pastoral communities.

Population pressure from within the pastoral system and its surroundings, climate change and drought occurrences as well as government policies (privatized land tenure systems, commercial agriculture and development projects) have undermined the customary practices that were instrumental in maintaining the ecosystem balance. Deforestation, especially by non-pastoral groups, and the establishment of permanent settlements have resulted in mismanagement and resource depletion. Competition over natural resources among different groups has now become rampant and often leads to violent conflict. Another daunting problem is lack of proper market access for pastoralists that does not negatively affect their nomadic existence and cultural way of life. Alleviating this problem is an important step because pastoral communities are the major suppliers of livestock and livestock products, and their success in marketing these goods largely depends on the accessibility of markets (in terms of distance from specific locations), types of market exchange (i.e., their integration into the cash economy), the demand for their produce and competition from other producers (Abule et al., 2005; Abule et al., 2007).

The rangelands of Ethiopia cover about $62 \%\left(682,000 \mathrm{~km}^{2}\right)$ of total land area of the country (EARO, 2002). These areas support different types of livestock and they are the major browsing and grazing areas of the country. In the extensive communal lowland grazing areas of Ethiopia, herbaceous and woody plants are the major feed source of livestock, which support more than $90 \%$ of the domestic ruminants (Mengistu, 2004). The main pastoral communities are the Somali (53\%), Afar (29\%) and Borana (10\%) living in the southeastern, northeastern and southern parts of Ethiopia, respectively (ANRS, 2010). Ethiopian pastoralists raise a large portion of the national herd estimated at $42 \%$ of the cattle, $7 \%$ of the goats, $25 \%$ of 
the sheep, 20\% of the equines and all of the camels (PFP, 2010). Over the years, records show that rangelands for pastoralists have experienced marked by drastic events, such as environmental degradation and climate variability, which are contributing to recurrent drought, rainfall declines, loss of livestock and shrinking rangelands that exceed those predicted by models of future climate. This is the drive behind for the communities in these regions to develop indigenous mechanisms and strategies to cope with those harsh conditions (Nyong, 2007).

The SNRS region occupies a large geographical area in the eastern and southeastern parts of Ethiopia. It lies between $4^{\circ}-11^{\circ} \mathrm{N}$ and $40^{\circ}-48^{\circ} \mathrm{E}$ and covers an estimated area of $340,000 \mathrm{~km}^{2}$. It is bounded by Kenya and Somalia to the south, the Republic of Djibouti and the Afar region to the north, Somalia to the east and southeast and OromiyaNational Regional State to the west. The SNRS is subdivided into nine administrative zones, namely Afder, Degehabur, Fiq, Gode, Jijiga, Korahe, Liben, Shinile and Werder, and fifty three Woredas (district). The SNRS falls under the arid and semi-arid agro-ecological and climatic zone. Its altitude ranges from $400 \mathrm{~m}$ in the southeast to about $1000 \mathrm{~m}$ in the north. In some hilly areas the maximum elevation goes up to $1600 \mathrm{~m}$ (Gebre-Mariam, 2007). The SNRS, with $90 \%$ rangelands, is a major pastoral area of the country (SORPARI, 2005). This makes rangeland utilization by livestock the largest land-use system in the country. The Wabi Shebelle, Genale and Dawa are the major perennial rivers, but there are also seasonal rivers such as the Fafem, Jerer, Dakata and Erer that flow in a north to south direction. The higher altitude areas receive as much as $600 \mathrm{~mm}$ rainfall per annum (semi-arid) whereas the larger, low-lying areas, in the south of the region receive only $300 \mathrm{~mm}$ rainfall or less (arid). This paper attempts to present a critical review of the rangeland resource degradation and management aspects in the SNRS.

\section{Objective of the Study}

The general objective of this study is to review the status of rangeland degradation and its management/ rehabilitation mechanisms and efforts in the SNRS in Ethiopia. The specific objectives are to: (i) review the status of rangeland resources; (ii) explore the nature, extent and causes of rangeland degradation; and (iii) assess the indigenous and modern rangeland management/ rehabilitation strategies, and efforts in the SNRS.

\section{Overview of Pastoralism in Ethiopia}

The entire geographic and economic peripheries of Ethiopia have for centuries been inhabited and worked by pastoralists, those engaged in livestock herding. The pastoralist areas in Ethiopia are generally classified as Kolla (dry lowland), which lies below $1500 \mathrm{~m}$, and having a low annual average precipitation of 400-700 mm (Yacob, 2000). The agro-ecology of these areas can be classified as arid, semi-arid and sub-humid zones. These zones vary markedly in terms of length of growing period, forage production, common plant associations, livestock and human carrying capacities and incidence of important livestock diseases (Coppock, 1994). The pastoralist areas are further characterized by the expansive and undulating plains of the lowlands, which are often crossed by trans-boundary perennial rivers. The Abbay, Tekeze, Omo, Wabishebelle, Baro-Akobo and Genale-Dawa river systems splendidly meander through the pastoralist territories before they are bound to cross the frontiers of the nation, in almost all directions. Not only the trans-boundary rivers, but also the internal rivers, like the Awash and Woiyto, cut across pastoral territories. The numerous lakes of the Rift Valley also lie in the pastoralist areas. Various studies and reports indicated that the pastoral areas represent about $62 \%$ of the country's landmass and are home to $12 \%$ of the human and 26\% of the livestock population. According to Coppock (1994), Hogg (1997), and Sandford and Habtu (2000) the main pastoral communities in Ethiopia are: (i) Somali (53\%), eastern part of the country; (ii) Afar (29\%), north eastern part of the country; (iii) Borana (10\%), southern part of the country; (iv) the remaining 8\% are found in the south western (Dasenetch, Hammer, Mursi, Bodi, Bumie, Bena, Erbore, Tsemay, Nuer, Anuak, Ari, Bali, Dime, Nyangtom, Chai, Trima, Ruli and TinshanaMuguuji) and western (Komo, Shinasha, Gumuz and Benshangul) parts of the country.

Although there are various adaptive specializations in these groups, the majorities are pastoralists. These areas are, thus, important sources of livestock to the nation. For instance, cattle and sheep in these areas made up over $90 \%$ of the total live animal exports in the mid-1980. Cattle in these areas also provide around $20 \%$ of the animals required in the highlands for Dryland Husbandry Project in Ethiopia draft power (traction) and for cross breeding in smallholder dairy programs (Coppock, 1994). Generally speaking, in Ethiopia, a pastoral specialization may not be confined to a particular ethnic group, but rather should be an adaptive feature of any group living under certain conditions that make extensive livestock keeping an effective way of utilizing natural vegetation. Historically, different groups may emphasize different aspects of their economic specialization over time. In spite of the many varieties of pastoralism in Ethiopia, dependence on livestock, marginal environment, geographical location and political marginalization are the key common features for all. Although, the pastoral areas of Ethiopia are endowed with enormous economic potentials, the predicaments of Ethiopian pastoralists have increased over the past several years, and it is likely this trend may continue at an alarming rate (Diress, 1999).

According to Yacob (2000), resource shrinkage and tenure insecurity are the two major problems facing pastoralists in Ethiopia. The internal and external factors worked steadily towards the shrinkage of pastoral resources in Ethiopia. Internally slow, but steady shift has taken place to cultivation activities with a resulting pressure on the prime grazing resources. Externally, the pastoral resources have been affected by the unabated encroachment on the grazing lands by agribusiness, national parks, game reserves, mineral prospecting, etc. The pastoral areas of Ethiopia were politically conceived by previous governments as "no man's land", and because of this reason, the land laws regarded them as state 
property. Land tenure laws provided all "unsettled" or permanently uncultivated land, as state-owned land. Hence, the land under pastoral use has been subjected to re-assignment to various non-pastoral uses by outside actors.

Ahmed et al. (2002) also indicated that the pastoral production system in Ethiopia is threatened by population growth, privatization of grazing land and water resources, land use shift in favour of sedentary farming and inappropriate livestock development projects attempted in different periods. The various pressures mentioned, coupled with recurrent drought in these areas, threatened the production system and the livelihoods of pastoralists in the country. Although not successful, attempts were made by the previous governments to improve the livelihoods of the pastoralists in Ethiopia through various development projects.

\section{Status of Rangeland Resources in SNRS}

In the SNRS woodlands and bushlands are the dominant forest resources. These constitute various groups of thornless and thorny bushes and shrubs, native Acacia, Commiphora, Boswellia and other tree and shrub species. The vegetation varies from relatively dense in the upper parts through scattered shrub-land with sparse to dense grass ground cover along the fringe of the highland and barren lands in the southeastern corner of the Region. There are species of grasses typical to the arid and semi-arid climates that are the major source of livestock feed. Acacia and Commiphora woodlands are known to be with the highest number of endemic species that contain families with high species diversity. The number of individual endemic species is estimated at 800 out of 1600 plant species found in the Region, which represents $25 \%$ of the country's total flora. Natural high forests do not exist in the Region, though Friis (1992) reports that there are some in the western parts that are closer to the highland areas. Plantation forests per se do not exist in the Region (EPEMRDA, 2011).

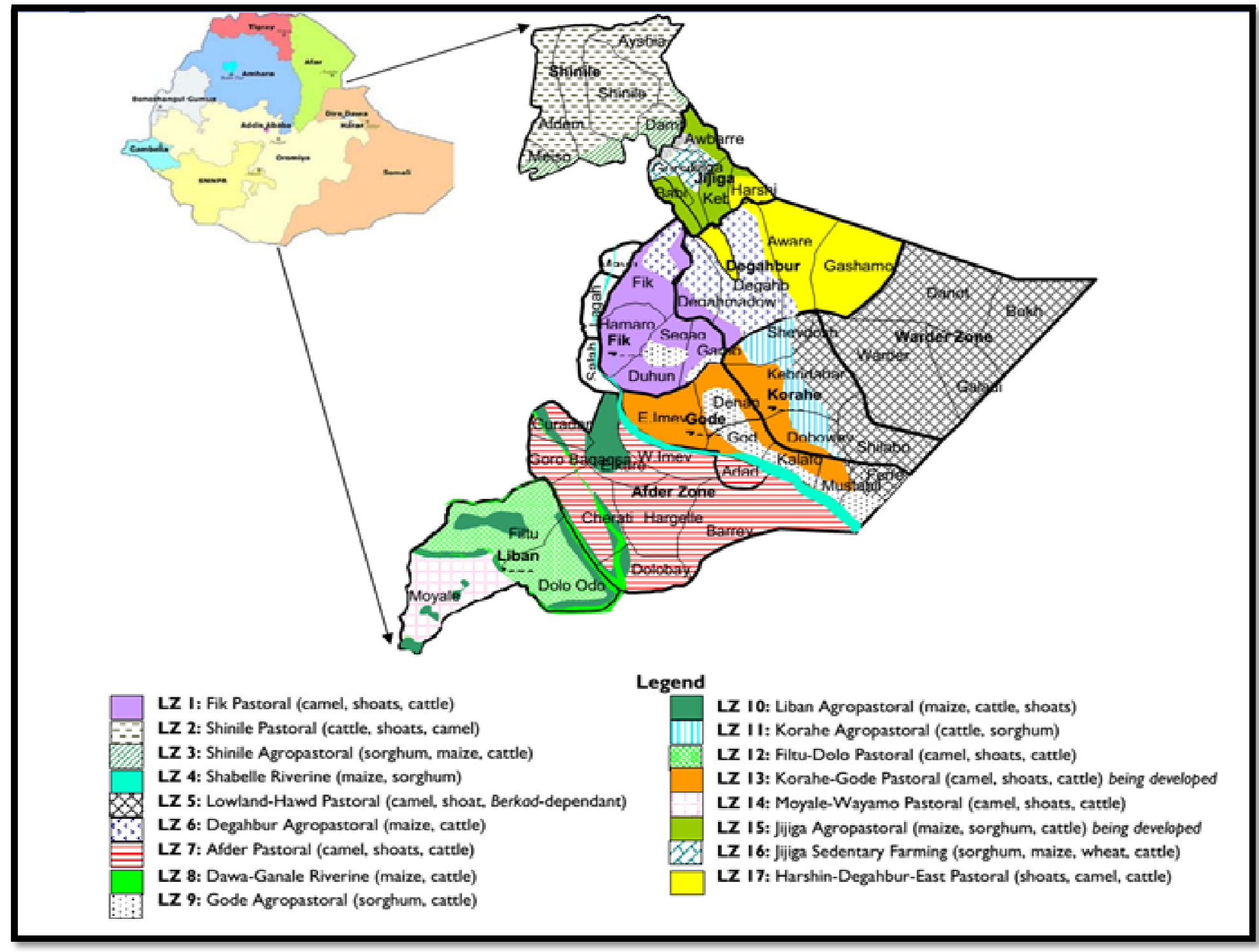

Figure 1: Location and Livelihood Map of SNRS (Source: Food Economy Group, 2007) 


\section{Nature, Extent and Causes of Rangeland Degradation in SNRS}

\subsection{Nature of Rangeland Degradation}

Significant climatic variability continues to be a common phenomenon in the northeastern lowlands of Ethiopia, including the SNRS. Frequent and persistent droughts, unpredictable and variable rainfall and temperatures are considered normal climatic conditions, especially in the arid and semiarid pastoral lands. Ecosystems within rangelands are characterized by low-stature vegetation because of temperature and moisture restrictions. Vegetation tends to be sparse but the sparse grass/ herbaceous cover is efficiently harvested by grazers and, in many cases, episodic fires are important for providing new and lush growth for grazers. However, recent changes in the climate system have brought about rapid changes, which have affected natural resources as well as the cultures and life styles of the pastoralists in the lowland regions. The rangelands, which constitute a major renewable resource in a highly vulnerable, diverse and difficult environment, have been most affected by these changes. Rangeland degradation is the most serious challenge for pastoral livelihoods in SNRS. Major reduction in the quantity and nutritional quality of the vegetation available for grazing in the rangelands as well as expansion of localized deserts and barren areas are common features of the region. The major causes of degradation include climatic conditions, causing drought and arid conditions and human factors leading to the overuse of natural resources (EPEMRDA, 2011).

The effects of climate change and human pressures on the soil include a depletion of soil nutrients, with a decline in water retention, which ultimately causes a breakdown in soil structure and inability of some local breeds to cope with such changes. The pattern of such changes in the SNRS and within its five administrative zones vary from place to place with the seasonality and variability of the climate system, the movements and concentration of grazing animals, with seasonal conditions and varying vulnerability of the land itself. In some locations, where years of drought induced overgrazing and, hence, led to important land degradation, infestation with P.julifiorahas a strong negative impact on grazing availability. Generally, the continuing or accelerating course of rangeland degradation include (EPEMRDA, 2011):

- Deterioration in the quantity, quality and persistence of native pastures, generally associated with a diminution of plant cover, but also with invasion by shrubs of low pastoral value; frequently unpalatable and of little economic value or practical use;

- Structural changes in the plant cover, notably the loss of shrubs and trees, partly through browsing, but also through gathering of fuelwood and clearing and burning for opportunistic farming; and

- Changes in soil surface conditions, notably compaction through trampling by livestock, leading to deterioration in soil - plant - water relationships and reduced germination rate, particularly of the palatable species.

Additional processes of sand drift siltation, leads to further destruction of the vegetation and commonly to deterioration of surface and shallow groundwater supplies (Kassahun et al., 2008a; Roba and Oba, 2009; Brink and Eva, 2011; Solomon et al., 2007; Gemedo et al., 2006). Even though people have adapted to changes and the harshness of these highly variable environmental conditions through generations (Fratkin, 2001), in the light of the ongoing rates of environmental changes and continued population increases, their ability to adapt may become threatened (Holmgren and O“ Berg, 2006; Samson et al., 2011). Understanding the extent and effects of climatic, and land use and land cover changes on livelihoods and, indirectly, adaptive capacity at regional and local scales has never been more important given that almost 50\% of the earth's natural ecosystems have already undergone some type of alteration (Barnosky et al., 2012).

While there is a number of disparate, small-scale studies addressing some of these components in the region (Brink and Eva, 2011; Reid et al., 2000; Serneels et al., 2001; Vanacker et al., 2005; Kiage et al., 2007), the majority of work is either anachronistic or remains based on fairly location-specific survey data (Abule et al., 2005; Desta and Coppock, 2004; Luseno et al., 2003). The high variability of the intra-annual rainfall distribution is the main constraint for vegetation growth. Generally, the vegetation of the region is mirrored in the climatic patterns. The vegetation is characterized by a highly variable mosaic of land covers, ranging from semi desert to desert ecosystems, but generally dominated by grasslands interspersed by woody vegetation, especially in the drier rangelands of the region. While research on land cover change and rangeland degradation for the Somali region remains relatively limited, studies point to increasing environmental and rangeland degradation (Kassahun et al., 2008b; Roba and Oba, 2009; Brink and Eva, 2011; Solomon et al., 2007; Gemedo et al., 2006).

Recent work also shows that this area is, especially, susceptible to environmentally-driven pastoral conflicts, which are linked to the increasing rainfall variability and decreased land availability associated with rangeland degradation (Meier et al., 2007). Additionally, some sources cite elevated levels of rangelands degradation such that cattle are no longer viable and are becoming replaced with camels by subsistence pastoralists (Kassahun et al., 2008a). The need for an integrated regional scale assessment centered on the pastoralist and agro-pastoralist regions of the region has never been greater, given the fragility of these ecosystems and the socioeconomic burdens imposed by observed climate change impacts.

\subsection{Extent and Causes of Rangeland Degradation}

The degradation of sparse rangeland vegetation by overgrazing exposes the soil to erosion by wind and water. Ethiopia has one of the largest livestock populations in Africa with 30 million heads of cattle, 22 million sheep, 17 million goats, 7 million equines and 1million camels (CSA, 2006). Livestock pressure and poor stock management (mainly based on the free grazing 
system) are other major sources of land degradation. These contravene in the soil nutrient cycle seriously depleting soil quality, increasing erosion and eventually reducing soil productivity (MoARD, 2007).

\subsubsection{Lack of Support for Pastoralism and Inappropriate Land Use Planning}

The establishment of water points or exclosures is often used to provide short-term relief during drier periods, but in the longer-term these are also likely to contribute to rangeland fragmentation. For example, the establishment of water points and private enclosures in both northern Kenya (Enghoff et al., 2010; Walker and Omar, 2002; Kitalyi et al., 2002) and Ethiopia (Sugale and Walker, 1998) may have had immediate benefits, but have also contributed to rangeland fragmentation. In the eyes of land use planners and decision makers, pastoralism is often not recognized as successfully competing with other land uses, and the pastoral system as a whole gets inadvertently destroyed by the removal or blocked access to its key resources. Conversion for large-scale agricultural irrigation schemes, introduced as part of agriculture-led development policies, have been a major cause of rangeland fragmentation (Yacob and Catley, 2010).

\subsubsection{Developments in the Charcoal Industry}

Charcoal production in the SNRS has existed for the last fifteen years, but for most of this time it was on a very small scale and for domestic purposes only. It was only after the 1998 export ban to the Middle East that charcoal production began to be undertaken on a commercial level. By this time, the expanding urban population in nearby towns over the border in Somaliland had increased demand for charcoal and promoted the cross-border charcoal trade in places, such as Harshin that is so evident today. Before this growth in the late 1990s, charcoal production and trade were seen as a last resort for destitute pastoralists. Society looked down upon charcoal producers who were subject to insults such as "...a charcoal producer never wearsa white shirt". However, nowadays the main operators in the charcoal trade are not poor pastoralists but wealthy businessmen, often from the region, who organize and finance mass production through the mobilization of local communities (EPEMRDA, 2011).

The involvement of Somali pastoralists in new livelihoods should come as no surprise. Customarily, the Somali pastoral economy has relied heavily on livestock herds, but it has always been linked to the wider regional markets. This economy has steadily diversified as a result of the growing uncertainty of 'pure' pastoralism although it has often been women rather than men who have ventured into new avenues of income generation. Previously, providing for a household was solely the responsibility of men, but with recurrent droughts the livestock component of household income has been eroded. Today, in many households women provide some or even all of the income through small scale trading. The reluctance of men to move into more commercial activities (with the exception of large livestock) means that women sell the majority of shoats as well as khat and control a significant proportion of the charcoal trade (Devereux 2006).

In general, we can identify a number of push and pull factors that explain the attraction of the charcoal business for different stakeholders. For some groups it is a livelihood necessity, whereas for others it is for asset saving and wealth accumulation. Border regions in Ethiopia, including Harshin, have supplied this demand. The ease with which producers in these areas can export charcoal across the border due to the lack of controls on both sides make the business accessible to many people. Oxfam GB in 2005 calculated that roughly 63,000 sacks of charcoal are harvested from Harshin Woreda alone and are transported across the border to Hargeysa on a monthly basis utilizing 27,300 trees that are better browsed by browsers (APD \&Interpeace, 2006).

The production and cross-border marketing of charcoal in HarshinWoreda has resulted in various environmental and social consequences. According to the community's own perception, the various impacts of the charcoal industry are clearly visible in their day-to-day life. Some of these consequences have differential impacts on women and men. Environmentally, charcoal production is entirely unsustainable and depletes forest and rangeland resources. Rangeland degradation is already in evidence with increased soil erosion from wind and runoff. In addition to the trees burnt for charcoal, other plants and shrubs are used for fuel, reducing the availability of natural resources in general. As a result, some species are becoming locally exterminated and many animals are no longer seen in such great numbers. Over many years, this may lead to climatic change and a further increase in drought and other environmental shocks. Economically, the livestock sector will suffer from reduced forage resources, leading to a drop in the major pastoral products (milk, meat and hides). Fuelwood and construction materials will also become increasingly difficult to find, increasing workloads, particularly, of women. In general, it is believed that charcoal production is more severe than overgrazing as a cause of rangeland degradation, because acacia species that are important fodder resources for goats and camels are more rapidly depleted (EPEMRDA, 2011).

\subsubsection{Competition Over Land}

Livestock density and grazing patterns lead to overgrazing, which is one of the major causes of land degradation. Overgrazing results when livestock density becomes excessive and too many animals are grazed at the same area of rangeland, leading to degradation of vegetation and compaction and erosion of the soil. The uncontrolled browsing of trees and shrubs is another aspect of overgrazing and a patent cause of deforestation, leading to flooding and siltation in adjacent areas because rains are no longer held back by the sponge effect of the trees and carry with them large loads of eroded soil. Overgrazing also leads to soil erosion. 
According to (2005), the potential for conflict over land is pronounced when "a large landless or land-poor population has limited livelihood opportunities" and "a marginalized population depends on a small piece of land for subsistence and survival." Both apply, to some extent, to the SNRS, as livelihood opportunities are scarce and almost entirely dependent on the land. Of course, the land available is not small by most measures, but usable land is limited given the nature of the terrain, especially in times of drought. This sets up inevitable conflict over land, which is not a new phenomenon in Somali society. But exacerbating the situation are relatively new and competing ideas over how land should be owned and used. The livelihood changes convert into new types of conflict over land. In Somali society, land is traditionally communally owned; one common understanding is that all land "belongs to the unborn, living and dead". According to the federal government, all land is owned by the state, though in 2005, a law was passed granting regional government authority over land issues.

Land privatization, in turn, has become the "dominant cause of conflict between herders and farmers." Not surprisingly, land privatization over the past two decades has led to something previously quite rare in Somali society: the demarcation and exclosure of land. The first exclosures were established in the 1980s, and there has been a tremendous growth of exclosures after 1990. This practice of increasing individual ownership of land is contrary to the traditional communal use of land. The erection of physical boundaries demarcating land-an overtly physical statement of land ownership-only heightens the potential for conflict. These changing norms of land ownership create potential for conflict over land between those accustomed to the traditional notion of communal land ownership (including pastoralists) and those with a preference for individual land rights (including agro-pastoralists and farmers, at least those with the opportunity to have rights to land) (Gebre-Mariam, 2007).

Finally, the transition towards agro-pastoral and farming activities intensifies the already intense competition for the most valuable land, which in most cases is land with the best access to water, usually, found on or near a riverbank. The need for farmland irrigation makes this especially valuable land for agro-pastoralists/ farmers. Hence, they tend to seek farmland with easy river access, sometimes competing with one another over that land. The land demand for riverbank cultivation doubled over the past fourteen years. However, pastoralists continue to need drinking water for their herds and with many wells drying up during the recent drought, river water becomes an even more valuable commodity. When desperate pastoralists opt for more pasture and water resources beyond their traditional terrestrial limits of the clans, the conflict within and between clans, sub-clans and lineages of the same group of pastoralists and agricultural groups becomes inevitable. With increasing frequency, pastoralists are bringing their herds to the rivers to drink and the herds must pass through farmland often belonging to a different clan on the way (Gedi, 2005).

\subsubsection{Negative Environmental Challenges}

Pastoralism has historically been a sustainable livelihood option. However, increased environmental stresses and changes in policies and practices, including restricting access to land and water, have increased the environmental impacts of pastoralism. The major environmental challenges are mentioned bellow.

\subsubsection{Overuse of Water Resources}

Since many pastoral systems operate in dry lands, access to water is a limiting factor when determining herd sizes for many individuals and communities. As such, there is a high risk that competition for water may lead to overuse. This is especially true when considering the additional water needs of wildlife. In some drought prone areas of the region, for example, $58 \%$ of the water demand is met from groundwater. As such, in times of drought, there is insufficient supply to meet demand resulting in the drying of water-holes, the disruption of natural water flows and siltation of pans (Ahmed et al., 2005).

\subsubsection{Overgrazing}

As a result of increased population and herd sizes and reduced land access due to factors, such as degradation and conversion to other land uses, overgrazing has increasingly become an issue for the Somali pastoralists. The impacts of overgrazing include loss of vegetative cover and associated soil erosion in the most extreme cases, with negative impacts on wild grassland species as well as inland waterways, which can suffer from sedimentation. In less severe cases, overgrazing can lead to a shift in the composition of grassland species with high nutritional value species becoming less predominant while less palatable plants increase in number. A study of pastoral systems in north of the region, for example, revealed that while overgrazing was not reducing biodiversity, it was changing the composition of the ecosystem (Ahmed et al., 2005).

5.2.4.3. Livestock-Wildlife Conflicts

There are two main types of livestock-wildlife conflicts to consider in the region. The first is competition with other grazers for water and fodder, and the second is conflict with predators who feed on livestock. Conflict with other grazers tends to be most noticeable during periods of stress such as drought. During such periods, it is common for pastoralists to move herds into protected areas in search of water and fodder, a prime example to be taken is the case of GeraleNational Park in and around Moyaleand Hudat Woredas of LibanZone. In doing so, pastoralism comes into direct competition with wildlife. It is worth noting, however, that access to protected areas during times of drought can be vital to the survival of pastoralists' herds and can, therefore, have a significant impact on pastoralists' livelihoods and rangeland resource (EPEMRDA, 2011). 


\subsubsection{Migration-Related Land Degradation}

Worsening feed and water shortage is rendering pastoralists in the region to spend higher proportion of the year in migration. Migration has negative implications on rangeland ecology leading to sever rangeland degradation. Previous studies indicated that annually, 5 to 10 million ha of land become unusable due to severe degradation. About 1.4 to $2.8 \%$ of the existing agriculture, pasture and forestland will be lost by 2020 if such a trend continues. Livestock herders and their animals are increasingly involved in tracking long distances in order to reach the appropriate watering points and livestock grazing areas. As a result, many animals are being lost due to their poor body condition and disease attacks in the absence of good feed, and many succumb to early deaths on their way to a better pasture and browse (IFPRI, 2006).

\subsubsection{Bush Encroachment}

The trend of shortening and patchy rainfall distribution has resulted in an alarming replacement of palatable and nutritional important grazing and browsing species with woody and unpalatable ones. The disappearance of most valuable grasses and their replacement by less important annuals had become a common phenomenon in most part of the ShinileZone. Bush encroachment causes severe economic and ecological losses for pastoral communities in SNRS. Previous studies and official reports from the regional administration offices in the SNRS confirm that bush encroachment is the most important factor hampering sustainable livestock production, food security and improved livelihoods. Accordingly, the problem is becoming a threat to feed and food security in the area. In many parts of the SNRS, P.julifiora(locally called WoyaneZaf) infestation is so dominant that almost all other plants are suppressed and do not grow anymore. Prosopis tends to form dense impenetrable thicket. Hence, livestock are not able to graze underneath and have difficulties in movement and accessing the river water (EPEMRDA, 2011).

\subsubsection{Impact of Climate Change}

Significant climatic variability continues to be a common phenomenon in the northeastern lowlands of Ethiopia including the SNRS. Frequent and persistent droughts, unpredictable and variable rainfall and temperatures are considered normal climatic conditions, especially in the arid and semiarid pastoral lands. Ecosystems within rangelands are characterized by lowstature vegetation because of temperature and moisture restrictions. Vegetation tends to be sparse but the sparse grass/ herbaceous cover is efficiently harvested by grazers and, in many cases, episodic fires are important for providing new and lush growth for grazers. However, recent changes in the climate system have brought about rapid changes which have affected natural resources as well as the culture and life styles of the pastoralists in the lowland regions. The rangelands, which constitute a major renewable resource in a highly vulnerable, diverse and difficult environment, have been most affected by these changes. Generally, the continuing or accelerating course of rangeland degradation in the SNRS shows common features, including (EPEMRDA, 2011):

- Deterioration in the quantity, quality and persistence of native pastures, generally associated with a diminution of plant cover, but also with invasion by shrubs of low pastoral value; frequently unpalatable and of little economic value or practical use;

- Structural changes in the plant cover, notably the loss of shrubs and trees, partly through browsing, but also through gathering of fuelwood and clearing and burning for opportunistic farming;

- Changes in soil surface conditions, notably compaction through trampling by livestock, leading to deterioration in soil - plant - water relationships and reduced germination rate, particularly of the palatable species;

- Additional processes of sand drift siltation, leading to further destruction of the vegetation and commonly to deterioration of surface and shallow groundwater supplies.

- Water stress: water is the essential prerequisite for human life, environmental integrity, social well-being and economic activity. Its value is well appreciated in rural and semi nomadic communities where the inhabitants experience the frequent hardship of fetching water from long distance or driving their cattle for several days to water points. Such situations are even worse in several zones of the snrs where the climatic condition is arid and characterized by unreliable and erratic rainfall.

In SNRS, overgrazing and deforestation contributes to reduction of ground cover and accelerates erosion processes. Further threats to indigenous trees such as Acacia nilotica, A. tortilis are also posed by the high dependency on fuel wood and charcoal. Moreover, important grass species and wild food species, are either pushed to local extermination or are in a very short supply (IEA, 2002).

\section{Rangeland Management/ Rehabilitation Strategies and Efforts in SNRS}

\subsection{Control of Bush Encroachment}

Exotic and indigenous trees and shrubs are widely spread throughout semi-arid and arid Areas of SNRS. One of the major threats of bush encroachment is reduction of grass production. Out of the exotic tree species, P.juliflora is currently spreading and encroaching the grazing lands of the region and is causing severe negative impacts on the production and productivity of rangelands. This species is spreading at an alarming rate into best grazing areas in the Somali rangelands. Other species, such as Acacia drepanolobium, A. seyal, Lantana camara, Partheniumhysterophorus and species of Commiphora and Opuntia are also 
causing serious problems by encroaching dry and wet season grazing areas. Misconceptions of traditional resource management and the impact of fire ban have resulted in bush encroachment. Therefore, although there are a number of bush control methods that are practiced in different countries including mechanical, chemical, power (chaining) or bull-dozing, the simplest and most practical methods that can be used in Ethiopia, including SNRS, is burning. The usual method is to burn the perimeter of the area starting from the down-wind side moving towards the finish on the up-wind side. The nature of fire depends on the quantity of combustible material present on the ground. Therefore, an active burning is obtained when good ground cover dry matter is present on a reasonable bushed rangeland. Previous protection of the area to be burnt is often necessary and, hence, preparation of fire breaks prior to burning is essential to control unwanted damage. Burning should be done in hot, dry weather near the beginning of the rainy season. The burnt area should not be grazed in the early growing season following the burn until an adequate cover has developed. The primary advantage of using burning as a method of bush control is low cost. However, fire is not selective; it can destroy beneficial plant species which may also contribute to land degradation (Gebru, 2009).

\subsection{Resting of Pasture Land/ Deferred Grazing}

Deferred grazing means delayed grazing. This is the simplest and most effective range improvement and rehabilitation method that can be practiced if the idea is accepted and the set regulations are properly implemented by the beneficiaries. The longer the beginning of grazing on a range is delayed, the better the opportunity exists for new plants to become established and for old plants to gain vigor. If grazing can be deferred (rested) every few years, forage plants will have better opportunity to reproduce. Therefore, resting pasture land periodically from 3 to 12 months depending on the magnitude of the spoiled area and, then, allowing controlled grazing can improve forage productivity. Hence, the resting period should extend throughout one complete wet and dry season grazing period every 4 or 5 years. Since SNRS is vast and constitute diversified range vegetation, this coping strategy will be one of the best options (PFE et al., 2010).

\subsection{Water as a Tool for Range Management}

Low and erratic rainfall is characteristic of the Somali rangelands and pastoral production systems have always relied upon surface and ground water sources. Strategic water development interventions have significant impact in contributing to improving range utilization. Water is needed only where there is unutilized grass and, then, only in the quantities appropriate to optimal grazing use. The capacity of water points that can provide drinking water for livestock in a given period of time have to be related to the estimated usable forage in a given area. In the SNRS, factors affecting the appropriate density of water supplies are numerous and complex. Water points are important not only in terms of the grazing, which they permit in their vicinity, but also as transit points for animals on migration from one grazing area to another. Such reliable transit water points can be extremely important in permitting the movement of livestock, especially in terms of drought, from poor to good rangelands. In the absence of such water points, herds can be cut off and suffer great losses (Yami and Merkel, 2009).

Management of watering points varies from one pastoral area to another. In the SNRS, Birca (cistern) and Ella (hand dug wells) are normally owned and managed by individuals. The distribution and type of water points and watering schedules are major determinants of range use. Mobility management or trans-humans management is, thus, seasonal movements of livestock between well-defined pasture lands. In general, mobility in a non-equilibrium environment is a necessary phenomenon to sustainable development in which livestock is an integral part of conservation and development. Indigenous knowledge of pastoralists is employed in the management and use of rangeland resources. Indigenous or local knowledge can be defined as skills, practice sand technologies that are an integral part of the production system in a specific culture. These are the area-specific skills and practices concerning natural resource management, human and animal health, etc. developed by indigenous people over centuries. Therefore, it is important to take advantage of indigenous institutions, environmental knowledge and traditional management practices (Gebru, 2009).

\subsection{Movement between Dry Seasons}

Development of pastoral production systems in Ethiopia, especially in the Somali rangelands is facing significant constraints. The major constraint is that rangelands are increasingly unable to support pastoralists and their livestock. This is, primarily, the result of rapidly growing pastoral populations made worse by the loss of high potential rangelands to other types of land use. However, pastoralists exploit the available natural resources in a systematic way. Movement between dry season and wet season pasture is a traditional form of pasture rotation, deferment (resting of pasture land) and sometimes a means of avoiding disease outbreaks. The rational strategies of pastoralists can be efficient and complex. Such movement of livestock has the following benefits (Yami and Merkel, 2009).

- Dry season pastures are allowed a period of rest and growth during the wet season, which maintains and sometimes increases the plant biomass.

- Wet season pasture often has abundant natural ponds, thus, reducing the need for labor to water animals at least for part of the year.

- Period of rest breaks the cycle of disease and parasites that tend to build up around dry season wells. 


\subsection{Role of Development Agents}

NGO's play great roles in rehabilitating rangeland ecology, particularly, in pastoral communities including those in SNRS. These include (Gebru, 2009):

- Identify the pastoral/agro-pastoral leaders and progressive community members and create a close working relationship;

- Learn their indigenous knowledge regarding animal production, use of natural pasture, general conditions of dry and wet season grazing areas and animal health, and record important points for future use;

- Record local names of valuable plant species in the area used as livestock feed and other purposes and have them identified scientifically in order to know uses and potential problems from the literature.

- Identify major livestock problems of the area and discuss appropriate prevention or treatment measures with the community; participate in the implementation of planned interventions;

- Carry out inventories in the dry and wet seasons grazing area resources through discussions with community leaders and visual assessment to determine potential production and problems. Give emphasis to the following components: (i) livestock water sources by type (birca, bore holes, hand dug wells, ponds and rivers; (ii) status of grazing and browsing resources; and (iv) problems regarding resource use.

- Based on the rough assessment ofthe three components, namely, livestock number, amount of water and available forage, identify the magnitude of problems and suggest appropriate actions; and

- Mobilize the community through elders and progressive pastoralists to clear unwanted plant species at early stage (parthenium and prosopis) and participate during implementation.

\subsection{The Role of Traditional Institutions}

Pastoralist communities have accumulated centuries of experience and knowledge about resource management. Traditional institutions are run almost exclusively by older men who make decisions that affect everyone else in society. They set rules and regulations that forbid inappropriate practices, they ensure that rangeland resources are used and maintained properly. They also arbitrate disputes. The leadership negotiates with neighboring groups on the use of water and pasture and allocates range and water resources. Their key strategy is managing mobility; they decide if, when and where the community should move. Traditional management of pastoralist rangelands depends on careful and wise use of community knowledge. The main consideration is availability of pasture and water. To ensure the availability of good pasture, pastoralists practice herd splitting and range burning. Herd splitting conserves and safeguards range resources from being degraded and overgrazed and reduces competition among various livestock age groups. Herds and flocks are broadly split into base and satellite herds. In most pastoralist communities, very young animals are tended by the boys and girls while the men look after the adult herds at a distance from home. Lactating animals, which provide milk for families are herded near settlement centers while the dry and pregnant females travel long distances in search of pasture and water. Due to factors like increases in human population and land degradation, the practice of herd splitting is on the decline (Yami and Merkel, 2009).

Range burning encourages new and fresh grass growth, controls pests and keeps the bush healthy by destroying unwanted species. Dry pasture is often burnt at the end of the dry season. However, forest burning has been banned by government since the 1970s because of the danger of bush fires. As a result of the ban, rangelands have been invaded by invasive plant species, which prevent grass from growing. Cattle and sheep cannot feed on the bush unless it is managed and the bush is of no known economic value. Different pastoralist groups have different traditional institutions; hence, it is difficult to generalize about them. Most are based on social structures (groups of related people) or territory (where the person comes from). Everyone is a member of a lineage group or clan. These institutions vary even within a pastoralist society. For example, the Somalis in Liban and Afder have different systems from Somalis elsewhere (Yami and Merkel, 2009).

The Somalis are organized into clan families, clans, primary lineages, dia-paying groups, jiffo units and households. The primary lineage (a group of related dia-paying groups) is the most stable political unit within a shifting system of allegiances and alliances among clans and lineages. Somali leadership may consist of lineage, which is traced through the male line. Members of the dia-paying group share a common male ancestor 4-8 generation back. They accept responsibility for the actions of other members. Dia-paying groups are divided into jiffo units (up to 100 households) composed of a man's close relatives. These are all slightly different, but the specific roles of leaders in resource management can be seen in the example of the Garri clan. Their leaders oversee social and political matters and manage natural resources for their respective clans (PFE et al., 2010).

OdeyashaDeegankaare elders elected because of their in-depth knowledge of the Heer (traditional rules and regulations of the Garriclan). They are usually three or four though their exact number is flexible. The OdeyashaDeeganka are also responsible for the use and management of water and pastures, social welfare and conflicts at Maddaa level (a group of settlements depending on the same permanent water source). HogamiyahaOlaha is the last position in the leadership hierarchies of the Garri clan. He is responsible for enforcing the Heer at grassroots level. He is a pious, generous individual well versed in the Heer of the clan. He deals with issues at settlement level, including marital disputes, conflicts at individual and household level and where to move in search of resources. TheGarri exercise herd and family splitting when they move. All family members with milking animals move and settle very close to water sources called ellas during the dry season. This is 
locally known as Ollok. The young herdsmen move all the other non-milking stock to distant areas, mainly close to big rivers. This is called Jill (Hurweyin) (Gebru, 2009).

\subsection{Response Measures Needed to Enhance Regional Capacity to adapting to Climate change}

Pastoral areas in Ethiopia are characterized by frequent drought and high livestock mortality that threaten the viability of pastoral livelihood and can lead to famine and human death. Apart from moving livestock to better grazing and watering areas during bad years, pastoralists also sell their livestock for grain and other needs as a coping mechanism during the onset of a drought. The nature of rangeland vegetation is strongly affected by man-made mismanagement activities. However, it is possible to return vegetation to a desired state through proper range management techniques. The best methods are applying proper stocking rate, resting of pasture land, over sowing of appropriate forage seeds on an open range and use of watering points in a balanced way (balance among water, livestock and available pasture) (Yami and Merkel, 2009).

Climate change is affecting dry land areas and livelihoods. Although long-term predictions are difficult, most climate change models suggest that many dry lands will become warmer and drier. As a result, existing water shortages will worsen and droughts are likely to become longer and more frequent. If rainfall becomes even more erratic, resources such as pastures will become scarcer, more scattered and harder to predict. This, coupled with population growth, would promote greater competition between resource users, possibly, resulting in social conflict and even violence. This demands action both to mitigate climate change and to support adaptation strategies in dryland areas. The latter entails helping people respond to change by, for instance, enabling herd mobility while securing pastoralists' rights to natural resources, supporting pastoral livelihoods and their diversification, and researching drought resistant crops (EPEMRDA, 2011). The adaptive capacity of a community is its ability to adjust to climate change, moderate or cope with the impacts and take advantage of the opportunities. Adaptive capacity is often determined by a range of factors, processes and structures, such as income, literacy, institutional capacity, social networks as well as access to information, markets, technology and services. Because the availability of these resources and services is limited in the region, the region's adaptive capacity in the face of climate change is correspondingly low compared with other regions of the country (IPCC, 2007).

However, there are a significant number of agro-pastoralists and sedentary agriculturalists. To support the agricultural sector, the regional Bureau has 2,667 development agents (DAs) with specialization in animal husbandry, plant science, animal health, small scale irrigation cooperatives and natural resource experts at the Woreda level. Livestock, crop and natural resource offices have 190 animal health assistance, 1,705 animal health technicians, 603 plant science professionals, 487 natural resource professionals, 110 cooperative professionals and 552 livestock production/ animal science professionals, and there are 20 small scale irrigation professionals that are giving services. With regard to these figures, one can conclude that according to the area of the region and the existing number of related professionals is far being enough. Therefore, the need to strengthen the region's capacity in terms of professional man power needs closer attention (EPEMRDA, 2011).

\subsection{Farming}

Dryland farmers have developed knowledge and innovations that enable sustainable farming in very difficult environments. However, in many areas farming is under pressure as a result of insecure land rights, conflict with other resource uses (particularly pastoralism), and unfair agricultural subsidies to the farmers by the donors. Supporting farming adapted to drylands requires, among other things, supporting farmers' innovation, promoting sound combinations of local knowledge and appropriate technologies, securing land rights, and regulating relations between competing resource users.

The experience with local conventions' developed by the region's pastoralists provides insights into ways of regulating farmerherder relations. These are community-based agreements on the management of shared natural resources that are negotiated by all interested natural resource users, usually with support from development projects. In Harshin area forest, for instance, local users with support from an NGO established rules and institutions that enable sustainable resource use on the one hand, and peaceful coexistence of competing resource users on the other.

Through training and action-research, pastoral groups gain a better understanding of the dynamics of their own livelihood system in relation to the broader policy environment, identify their own solutions to current problems, and are able to challenge outsiders' perceptions of pastoralism. Priority actions that should be tackled include:

Tackling dry land degradation: which requires working with governments and civil society to develop and implement policies and programs that:

- Secure local resource rights, promote peaceful coexistence between competing resource uses (e.g. Herding and farming) and enable pastoral mobility, both through support to design and implementation of appropriate national legislation and through support to local-level arrangements such as "local conventions" or other multi-stakeholder agreements;

- Support dryland livelihoods, including through better water management and supply and through off-farm diversification (particularly where this is the only viable option for the landless poor);

- Promote improvements in farming techniques and land use systems, through support to and valorization of local knowledge and innovation, and through appropriate combinations of local knowledge and locally appropriate technological innovations; 
- Promote restoration and rehabilitation of degraded dry lands, through soil and water conservation measures that are tailored to local contexts from terracing to nutrient replenishment and that are designed and implemented with the participation of local resource users;

- Strengthen the capacity of civil society in dryland areas to engage more effectively with policy debates on dry land development, including through training and exchange of ideas

Tackling water issues: sustainable and equitable management of scarce water resources for domestic and agricultural use is key to both poverty reduction and ecosystem protection in dry lands to decrease the burden of climate change. Again, environment and development goals are closely linked. Improving access to water is crucial but doing so without a proper understanding of local contexts may have negative social and environmental effects. Development programs that build water infrastructure inappropriately could result in resource degradation. In many pastoral systems, for instance, control over water sources needed by livestock enables regulation of access to surrounding grazing lands. Traditionally, resource management systems were centered on this close relationship between land and water rights: those digging wells enjoyed priority use rights over them and could regulate access to them by outsiders. In so doing, livestock numbers on a given rangeland could be controlled. (EPEMRDA, 2011).

Gully Control and Rehabilitation: severe land degradation is seen in many parts of the region and, hence, it should be addressed urgently using different techniques, such as small earth dams constructed across medium size gullies for sediment trapping, water collection, and diversion and overflow of excess runoff (Flintan et al., 2011). The space behind these structures is rapidly converted into fertile and productive fields. Important means to convert unproductive lands such as gullies into fertile fields have a beneficial influence in regulating water regimes and protecting downstream areas from excess runoff.

\section{Conclusions and the Way Forward}

In general, the rangeland resources in SNRS are suffering a severe degradation caused by intensive collection of fuelwood and building materials as well as overgrazing in some areas, while the cropping activities and urban settlements are more and more advancing into the rangelands. Livestock density and grazing patterns lead to overgrazing, which is one of the major causes of land degradation. Overgrazing results when livestock density becomes excessive and too many animals are grazed at the same area of rangeland, leading to degradation of vegetation and the compaction and erosion of the soil. The uncontrolled browsing of trees and shrubs is another aspect of overgrazing and a patent cause of deforestation, leading to flooding and siltation in adjacent areas because rains are no longer held back by the sponge effect of the trees and carry with them large loads of eroded soil. The natural vegetation near the permanent rivers and residential areas has been greatly influenced by different human activities within the last twenty years. Alongside the human overuse on the natural vegetation, the condition is aggravated by recurrent droughts, floods and widespread wind erosion in the dry seasons and water erosions in the rainy seasons. Often, huge areas of natural vegetation are destroyed so that they can be owned although the areas are not used for crops. Therefore, the conservation of natural vegetation must be given a number one priority to reduce the high risk of wind and water erosions, vegetation type and the loss of biodiversity.

The phenomenon of bush encroachment in SNRS has to be seen as a process of desertification. Not all woody plants in the rangelands are invasive. Whilst some woody plants have a potential positive role such as Nitrogen fixation when colonizing new sites, others, have negative effect on the growth of herbaceous plants. Invasive plants should be identified by working with local pastoralists.

In SNRS, the main encroaching bushes vary from zone to zone and from one site to another site. Major encroaching native woody species include Acacia nilotica, A.drepanolobium, A. mellifera and A.horrida. There are no accurate data as to the area covered and amount of encroacher plants in the region. These native invasive woody species can be controlled through thinning. Thinning improves watersheds by reducing encroachment of woody plants and amount of runoff. Opening up canopy provides enough light to the understory vegetation and allows adequate photosynthesis processes, allowing primary productivity of rangelands. It may also involve cutting at different heights of the invasive woody plants and uprooting short growing weeds. Thinning should be conducted by the end of dry seasons to cause maximum stress on the cut trunks. For example, A.drepanolobium can be eradicated if cut at knee height, 50 to $60 \mathrm{~cm}$, by the end of the long dry season.

Drought is a common event in Somali rangelands. Customary institutions have not only managed drought risks through drought reserves, but they have maintained healthy rangelands. Movement of herd to areas reserved for drought during scarcity allows grazing lands to rest leaving them in good conditions. Customary rangeland management institutions have reserved areas for drought as part of the reciprocal natural resource system seasonal land use. The Somali rangelands are characterized by unstable climatic conditions, which make drought unpredictable. Droughts may result from the disruption of rainfall pattern or extended dry season. The level of stress varies with the drought conditions. Extended time and distance to watering points and lack of forage induce increased livestock mortality, which is followed by scarcity of food for the human population. Access to drought reserves is regulated by watering regimes of cattle. Seasonal herd mobility also plays key ecological role in reducing land degradation, improving availability of rangeland resources and increasing local drought coping strategies.

Pastoral rangeland management faces multiple challenges caused by climate change, population growth, over grazing, bush encroachment and other factors. To combat all these drawbacks, pilot demonstrations are to be conducted to identify feasible rehabilitation option, which are economically feasible, culturally acceptable and environmentally friendly. Different technical approaches may be tested in different contexts and at different scales. Rangeland management officers have to facilitate pilot 
demonstrations, rather than impose, and support demand-driven technical demonstrations that integrate pastoralists. Participatory pilot demonstrations require good indicators, data collection and monitoring forms to monitor efficiency of technical options, document rate of change and assess impact on the environment. Thus, an area-wide rangeland resources inventory may be required to form the baseline information and an initial environmental examination assessed to ensure that the technical options being investigated are environment-friendly. The level of demonstrations may depend on the technical approach pursued, willingness of local pastoralists and availability of land. A key note from fieldwork is that experimental trials, i.e. data requirements, techniques and objectives should be harmonized with local conditions. A pilot demonstration may require up to two or more seasons. For example, more than two seasons may be required to rehabilitate bare lands fully whilst thinning of invasive woody plants may be possible in a month.

To develop the potential production of rangelands of the SNRS, the following solutions need to be planned:

- Improve land use management, which incorporates modern conservation strategies, including biological and physical soil and water conservation activities;

- A rangeland resource management program must be initiated in the near future in order to protect and improve rangeland condition and natural vegetation;

- Local rangers (guardians) who have the authority to protect communal rangelands, natural vegetation and wild animals should be deployed;

- More research is needed in the field of rangelands and rangeland management;

- Develop the use and sourcing of alternative energy and building materials;

- Improve awareness and education of local communities through formal and extension services; and

- Find or create a dependable market for the incense and gum products produced in the snrs.

To further strengthen the traditional system and support it with modern systems and technologies, the following appropriate interventions are recommended:

- Catchment treatment through land management, moisture and soil conservation and flood control methods;

- Implement soil and water conservation programs and projects that promote local community participation;

- Focus on rehabilitation and reclamation of degraded land, reforestation, conservation, management and protection of natural resources;

- Rehabilitate and manage dry season rangelands;

- Implement measures to control aggressive weeds and other invasive plants, such as p.juliflora, lanthanacamara and partheniumhysterophorus.

- Implementation of planting multipurpose trees at house hold level in areas where water is available from irrigation structures; and

- Promote somalis' various indigenous/ traditional natural resource management strategies such as:

- Mobility as the basis for vegetation management and utilization;

- Herd diversity;

- Ecosystem knowledge as the basis for vegetation management;

- Local institution;

- Fodder assessment and defined grazing as the basis for vegetation management; and

- Indigenous knowledge on species and their utilization.

\section{References}

i. Abule, E., Snyman, H.A. \&Smit, G.N. (2007). Rangeland evaluation in the middle Awash Valley of Ethiopia: I. Herbaceous vegetation cover. Journal of Arid Environments, 70, 253-271.

ii. Abule, E., Snyman, H.A. \& Smith, G.N. (2005). The influence of woody plants and livestock grazing on grass species composition, yield and soil nutrients in the Middle Awash Valley of Ethiopia. J. Arid Environ, 60, 343-358.

iii. Aerts R., Nyssen J. \& Haile, M. (2009). On the difference between "exclosures" and "enclosures" in ecology and the environment. Journal of Arid Environments, 73, 762-763.

iv. Ahmed, A.G., Azeze, A., Babiker, M., \&Tsegaye, D., T. (2002). Post-Drought Recovery Strategies among the Pastoral Households in the Horn of Africa: An Overview. Development Research Report Series No. 3. OSSREA, Addis Ababa, Ethiopia.

v. Ahmed, S., M., Hegde, B.P.\&Asefa, A. (2005). Reproduction breeding and management of female and male camels in Afder Zone of Somalia Regional State, Ethiopia. pp 67-76. In: Participatory Innovation and Research: Lesson for Livestock Development. Proceeding of the 12th Annual Conference of Ethiopian Society of Animal Production (ESAP), 12-14 August, Volume II, Addis Ababa, Ethiopia.

vi. Angassa, A. \& Oba, G. (2008). Herder perceptions on impacts of range enclosures, crop farming, fire ban and bush encroachment on the rangelands of Borana, southern Ethiopia. Human Ecology, 36, 201-215.

vii. Angassa, A., A. \&Beyene, F. (2003). Current range condition in southern Ethiopia in relation to traditional management strategies: The perceptions of Borana pastoralists. Tropical Grasslands, 37, 53-59. 
viii. ANSR (Afar National Regional State) (2010). Programme of Plan on Adaptation to Climate Change, Technical and Financial Support.Semera: Environmental Protection Authority ofthe Federal Democratic Republic of Ethiopia.

ix. APD \&Interpeace (2006). From Plunder to Prosperity: Resolving Resource-Based Conflict in Somaliland. Hargeysa: APD \&Interpeace.

x. Barnosky, A.D., Hadly, E.A., Bascompte, J., Berlow, E.L., Brown, J.H., Fortelius, M., Getz, W.M., Harte, J., Hastings, A., Marquet, P.A., Martinez, N.D., Mooers, A., Roopnarine, P., Vermeij, G., Williams, J.W., Gillespie, R.G., Kitzes, J., Marshall, C., Matzke, N., Mindell, D.P., Revilla, E. \& Smith, A.B. (2012). Approaching a state-shift in Earth's biosphere. Nature, 486, 52-58.

xi. Behnke, R. (1994). Natural resource management in pastoral Africa. Development Policy Review, 12 (1), 5-28.

xii. Behnke, R.H., Scoones, I. \&Kerven, C. (1993). Range Ecology at Disequilibrium. London: Overseas Development Institute.

xiii. Beyene, T. (2008). Kessem-Tendaho multipurpose water resources development, Ethiopia. Mexico City: Paper presented at the Fourth World Water Forum.

xiv. Bonger, G. (2009). Management for Proper Range Use in Ethiopia: Technical Bulletin No. 25. Addis Ababa: Ethiopia Sheep and Goat Productivity Improvement Program (ESGPIP).

xv. Brink, A.B. \& Eva, H.D. (2011). The potential use of high-resolution Landsat satellite data for detecting land-cover change in the Greater Horn of Africa. International Journal of Remote Sensing,32, 5981-5995.

xvi. Coppock, D.L. (1994). The Borana Plateau of Southern Ethiopia: Synthesis of Pastoral Research, Development, and Change, 1980- 1991. System Study No. 5. Addis Ababa: International Livestock Center for Africa.

xvii. Cowling, R.M., Esler, K.J., Midgley, G.F. \&Honig, M.A. (1994). Plant functional diversity, species diversity and climate in arid and semi-arid southern Africa. Journal of Arid Environments, 27, 141-158.

xviii. CSA (Central Statistics Authority) (2006). Agency, Federal Democratic Republic of Ethiopia Agricultural Sample Survey 2006/ 07, volume II, Report on livestock and livestock characteristics. Statistical Bulletin, 388, 9-10 \& 25-27. Addis Ababa: Central Statistics Authority.

xix. Dale, G. (2004). Vegetation Ecology, Rangeland Condition and Forage Resources Evaluation in the Borana Lowlands, Southern Oromia, Ethiopia. Göttingen: Ph.D. Thesis. University.

xx. Dale, G., Maass, B., \&Isselstein, J. (2006). Rangeland condition and trend in the semi-arid Borana lowlands, southern Oromia, Ethiopia. African Journal of Range \& Forage Science, 23, 49-58.

xxi. Desta, S. \&Coppock, D.L. (2002). Cattle population dynamics in the southern Ethiopian rangelands, 1980-97. Journal of Range Management, 55, 439-451.

xxii. Devereux, S. (2006).Vulnerable Livelihoods in Somali Region, Ethiopia. Research Report 57. Brighton: Institute of Development Studies at University of Sussex.

xxiii. Diress, T. (1999). Impact of land use on vegetation resource with emphasis on woody vegetation in the semi arid area of Abala District, North Afar Ethiopia. Haramaya: MSc Thesis, Haramaya University.

xxiv. EARO (Ethiopia Agricultural Research Organization). (2002). National Pastoral and Agro-Pastoral Research Document. Addis Ababa: Ethiopia Agricultural Research Organization.

xxv. Effershank, G., Effershank, J., Bryant, M. \&Whiteford, WG. (1978). Effects of nitrogen fertilization on primary production in a Chihuahuan desert ecosystem. Journal of Arid Environments, 1, 135-139.

xxvi. Enghoff, M., Hansen, B., Abdi, U., Gildestad, B., Owen, M. \&Obara, A. (2010). In Search of Protection and Livelihoods. Socio-economic and Environmental Impacts of Dadaab Refugee Camps on Host Communities. Report for the Government of Kenya. Nairobi: Royal Danish Embassy and Norwegian Embassy.

xxvii. EPEMRDA (Environmental Protection and Energy and Mines Resources Development Agency). (2011). Climate Change: Impacts, Vulnerabilities and Adaptation Strategies in Somali Region, Regional Program of Plan to Adapt to Climate Change.Jigjiga: Somali National Regional State.

xxviii. Eswaran, H., Lal, R. \& Reich, P.F. (2001). Land Degradation: An overview. In: Bridges, E.M., I.D, Hannam, \& L.R. Oldeman, F.W.T P. de Vries, S.J. Scherr, \& S. SompatPanit (Eds.). Responses to land Degradation. KhonKaen, Thailand: Proc. $2^{\text {nd }}$ International Conference on Land Degradation and Desertification.

xxix. FAO (Food and Agricultural Organization of United Nations) (2010). Global Forest Resources Assessment, FAO Forestry Paper 133. Rome: FAO.

xxx. Fernandez-Gimenez, M.E. (2000). The role of Mongolian nomadic pastoralists' ecological knowledge in rangeland management. Ecological Applications, 10, 1318-1326.

xxxi. Flintan, F., Tache, B. \&Eid, A. (2011). Rangeland fragmentation in traditional grazing areas and its impact on drought resilience of pastoral communities: Lessons from Borana, Oromia and Harshin, Jijiga: Somali National Regional States.

xxxii. Food Economy Group (2007). Summary of Outputs from the Livelihoods Integration Unit's Work in Capacity Building of Ethiopia's DPPA. Addis Ababa: The Food Economy Group.

xxxiii. Fourie, J.H., Opperman, D.P.J. \& Roberts, B.R. (1985). Evaluation of the grazing potential of grass species in Tarchonanthusveld of the Northern Cape. Journal of the Grassland Society of Southern Africa, 2, 13-17. 
xxxiv. Fratkin, E. (2001). East African Pastoralism in Transition: Maasai, Boran and Rendille Cases. African Studies Review, 44, 1-25.

xxxv. Friis, I. (1992). Forests and forest trees of northeast tropical Africa-their natural habitats and distribution patterns in Ethiopia, Djibouti and Somalia. Kew Bulletin Additional Series, 15, 1-396.

xxxvi. Gebre-Mariam, A. (2007). The Critical Issue of Land Ownership: Violent Conflict between the AbdallaTolomogge and the Awlihan in Godey Zone, Somali Region, Ethiopia (2nd Revised Edition). NCCR North-South Dialogue No. 11. Bern, Switzerland: Swiss National Centre of Competence in Research (NCCR) North-South.

xxxvii. Gedi, A. (2005). Herder-farmer Conflicts in the Dawa-Genale River Basin Area: The Case of Intra-Clan Conflict among the Degodia Somali of Dollo Ado District in the Somali National Regional State of Ethiopia. Bern: NCCR North-South.

xxxviii. Gezahegn, A.K. (2006). Characterization of Rangeland Resources and Dynamics of the Pastoral Production Systems in the Somali Region of Eastern Ethiopia. Bloemfontein: PhD Thesis, University of the Free State.

xxxix. Hogg, R. (1997). Changing Land Use and Resource Conflict among Somali Pastoralists in the Haud of South-East Ethiopia. In R. Hogg (Ed.), Pastoralists Ethnicity and the State in Ethiopia (pp. 105-22). London: HAAN Publishing.

xl. Holechek, J.L., Pieper, R.L. \&Herbel, C.H. (2001). Range Management, Principles and Practices (4th Edition). NJ: Prentice Hall, Upper Saddle, River.

xli. Holmgren, K., O"Berg, H. (2006). Climate Change in Southern and Eastern Africa during the past millennium and its implications for societal development. Environment, Development and Sustainability, 8, 185-195.

xlii. Hoppe, P.P., Qvorturp, S.A. \& Woodford, M.H. (1977). Rumen fermentation and food selection in East African Zebu cattle, wildebeest, Cock's hartebeest and topi. Journal of Zoology (London), 181, 1-9.

xliii. IFPRI (2006). Atlas of the Ethiopian Rural Economy. Washington: IFPRI. IIR, Cordaid and Acacia Consultants.

xliv. IPCC (Intergovernmental Panel on Climate Change) (2007). Climate change, impacts, adaptation and vulnerability: the Working Group II contribution to the Intergovernmental Panel on Climate Change Fourth Assessment Report. Cambridge: Cambridge University Press.

xlv. Jahnke, H.E. (1982). Livestock Production Systems and Livestock Development in Tropical Africa. KielerKiel, Germany: WissenschaftsverlagVauk.

xlvi. Kassahun, A., Snyman, H. \&Smit, G. (2008a). Impact of rangeland degradation on the pastoral production systems, livelihoods and perceptions of the Somali pastoralists in Eastern Ethiopia. Journal of Arid Environments, 72, 12651281.

xlvii. Kassahun, A., Snyman, H., Smit, G. (2008b). Livestock grazing behaviour along a degradation gradient in the Somali region of eastern Ethiopia. African Journal of Range \& Forage Science, 25, 1-9.

xlviii. Keene, F.B. (2008). Incentives and Outcomes of Rangeland Enclosures: A Comparative Institutional Analysis among three (Agro-) pastoral Districts in eastern Ethiopia. PhD diss.

xlix. Kiage, L.M., Liu, K.-B., Walker, N.D., Lam, N., \& Huh, O.K. (2007). Recent land-cover/ use change associated with land degradation in the Lake Baringo catchment, Kenya: evidence from Landsat TM and ETM+. International Journal of Remote Sensing, 28, 19, 4285-4309.

l. Kitalyi, A., Musili, A., Suazo, J. \&Ogutu, F. (2002). Enclosures to protect and conserve. For better livelihood of the West Pokot community. RELMA Technical Pamphlet No. 2. Nairobi:RELMA.

li. Luseno, W.K., Mc Peak, J.G., Barrett, C.B., Little, P.D. \&Gebru, G. (2003). Assessing the value of climate forecast information for pastoralists: evidence from Southern Ethiopia and Northern Kenya. World Development,31, 14771494.

lii. Makokha, W., Lonyakou, S., Nyang, M., Kareko, K.K., Holding, C., Njoka, T.J. \&Kitalyi, A. (1999). We work together: Land rehabilitation and household dynamics in Chepareria Division, west Pokot District, Kenya. RELMA Technical Report No. 22. Nairobi: RELMA.

liii. Mapinduzi, A.L., Oba, G., WeladJi, R.B. \&Olman, J. (2003). Use of indigenous ecological knowledge of the Maasai pastoralists for assessing rangeland biodiversity in Tanzania. African Journal of Ecology, 41, 329-336.

liv. Mc Naughton, S.J., Wallace, L.L. \&Coughenour, M.B. (1993). Plant adaptation in an ecosystem context: effects of defoliation, nitrogen and water on growth of an African C4 sedge. Ecology, 64, 307-318.

lv. Meier, P., Bond, D., \& Bond, J. (2007). Environmental influences on pastoral conflict in the Horn of Africa. Political Geography, 26, 716-735.

lvi. Meissner, H.H., Zacharias, P.J.K. \&O’Reagain, P.J. (1999). Forage quality (feed value). In: N.M. Tainton (Ed.), Veld Management in South Africa (pp. 169-192). Pietermaritzburg, South Africa: University of Natal Press.

lvii. Mengistu, A. (2004). Pasture and Forage Resource Profiles of Ethiopia. Addis Ababa: Alemayehu Mengistu and Associates.

lviii. MoARD (Ministry of Agriculture and Rural Development) (2007). Thematic papers on land degradation in Ethiopia. Addis Ababa: World Bank Publication.

lix. $\quad$ Mureithi, S.M., Verdoodt, A., Gachene,C.K.K., Njoka, J.T., Wasonga, V.O., De Neve, S., Meyerhoff, E. \& Van Ranst, E. (2014). Impact of enclosure management on soil properties and microbial biomass in a restored semi-arid rangeland, Kenya. Journal of Arid Land,6(5): 561-570. 
lx. Noy-Meir, I., Gutman, M. \& Kaplan, Y. (1989). Response of Mediterranean grassland plants to grazing and protection. Journal of Ecology, 77: 290-310.

lxi. Nyong, A. (2007). The Value of indigenous knowledge in climate change mitigation and adaptation strategies in the African Sahel. Mitigation and Adaptation Strategies for Global Change, 12(5),787-797.

lxii. Oba, G. \&Kotile, D.G. (2001). Assessments of landscape level degradation in southern Ethiopia: pastoralists versus ecologists. Land Degradation and Development, 12, 461-475.

lxiii. Opiyo, F.E.O., Ekaya, W.N., Nyariki, D.M. \&Mureithi, S.M. (2011). Seedbed preparation influence on morph metric characteristics of perennial grasses of a semi-arid rangeland in Kenya. African Journal of Plant Science, 5(8), 460-468.

lxiv. Own-Smith, N. (1999). The animal factor in veld management. In: N.M. Tainton (Ed.), Veld Management in South Africa (pp. 117-133). Pietermaritzburg, South Africa: University of Natal Press.

lxv. PFE, IIRR \& DF. (2010). Pastoralism and Land: Land tenure, administration and use in pastoral areas of Ethiopia. Addis Ababa: Pastoralist Forum Ethiopia.

lxvi. PFP (Pastoralist Forum Ethiopia) (2010). Pastoralism and Land Tenure, Administration and Use in Pastoral Areas of Ethiopia. Addis Ababa: Pastoralist Forum Ethiopia.

lxvii. Reid, R., Kruska, R., Muthui, N., Taye, A., Wotton, S., Wilson, C. \&Mulatu, W. (2000). Land-use and land-cover dynamics in response to changes in climatic, biological and socio-political forces: The case of southwestern Ethiopia. Landscape Ecology, 15, 339-355.

lxviii. Roba, H. \& Oba, G. (2009). Efficacy of integrating herder knowledge and ecological methods for monitoring rangeland degradation in northern Kenya. Human Ecology, 37, 589-612.

lxix. Samson, J., Berteaux, D., McGill, B.J. \& Humphries, M.M. (2011). Geographic disparities and moral hazards in the predicted impacts of climate change on human populations. Global Ecology \& Biogeography, 20, 532-544.

lxx. Sandford, S,\&Habtu, Y. (2000). Emergency Response Interventions in Pastoral Areas of Ethiopia. London, UK: Department for International Development (DFID).

lxxi. Sarmento, G. (1992). Adaptive strategies of perennial grasses in South American savannas. Journal of Vegetation Science, 3: 325-336.

lxxii. Schlee, G. (2003). Redrawing the map of the Horn: The politics of difference. Africa: Journal of the International African Institute, 73(3), 343-368.

lxxiii. Schlesinger, W.H., Reynolds, J.F., Cunningham, G.L., Huenneke, L.F., Jarrell, W.M., Virginia, R.A. \&Whitford, W.G. (1990). Biological feedbacks in global desertification. Science, 247, 1043-1048.

lxxiv. Serneels, S., Said, M.Y. \&Lambin, E.F. (2001). Land cover changes around a major east African wildlife reserve: the Mara Ecosystem (Kenya). International Journal of Remote Sensing, 22, 3397-3420.

lxxv. Snyman, H.A. \& du Preez, C.C. (2005). Rangeland degradation in a semi-arid South Africa-2: Influence on soil quality. Journal of Arid Environments, 60, 483-507.

lxxvi. Snyman, H.A. (2005). Rangeland degradation in a semi-arid South Africa 1: Influence on seasonal root distribution, root/ shoot ratios and water-use efficiency. Journal of Arid Environments, 60, 457-481.

lxxvii. Snyman, HA. (1998). Dynamics and sustainable utilization of the rangeland ecosystem in an arid and semi-arid climate of southern Africa. Journal of Arid Environments 39: 645-666.

lxxviii. Solomon, T., Snyman, H., \&Smit, G. (2007). Cattle-rangeland management practices and perceptions of pastoralists towards rangeland degradation in the Borana zone of southern Ethiopia. Journal of Environment Management, 82, 48494.

lxxix. SORPARI. (2005). Fafam Integrated Research and Development Project Feasibility Study and Planning. , Jigjiga, Ethiopia: Somali Region Pastoral and Agro-Pastoral Research Institut.

lxxx. Sugule, J. \& Walker, R. (1998). Changing Pastoralism in the Ethiopian Somali National Regional State (Region 5). Addis Ababa: UN Emergencies Unit for Ethiopia and SERP.

lxxxi. Swemmer, A.M., Knapp, A.K. \&Snyman, H.A. (2007). Intra-seasonal precipitation patterns and aboveground productivity in three perennial grasslands. Journal of Ecology, 95, 780-788.

lxxxii. Teketay, D., Kashe, K., Madome, J., Kabelo, M., Neelo, J., Mmusi, M. \&Masamba, W. (2018). Enhancement of diversity, stand structure and regeneration of woody species through area exclosure: the case of a mopane woodland in northern Botswana. Ecological Processes, 7, 5.

lxxxiii. ' 't Mannetje, L. \& Jones, RM. (2000). Grassland vegetation and its measurement. In: L 'tMannetje\& R.M. Jones (Eds.), Field and Laboratory Methods for Grassland and Animal Production Research (pp. 1-8). Wallingford, UK: CABI Publishing. Mannetje, L., Jones, R.J. \&Stobbs, T.H. (1976). Pasture evaluation by grazing experiments. In: N.H. Shaw (Ed.), Tropical Pasture Research Principles and Methods (pp. 222-234). Farnham Royal, UK: Commonwealth Agricultural Bureau.

lxxxiv. Turner, N.J., Ignace, B. \& Ignace, R. (2000). Traditional ecological knowledge and wisdom of aboriginal peoples in British Columbia. Ecological Applications, 10, 1275-1287.

lxxxv. UNCCD (United Nations Convention to Combat Desertification) (2013). A Stronger UNCCD for a Land-Degradation Neutral World. Bonn: United Nations Convention to Combat Desertification. 
lxxxvi. USAID (2005). Forests and Conflicts. A Toolkit for Intervention. Washington: USAID/ Office of Conflict Management and Mitigation.

lxxxvii. USAID 2005: Forests \& Conflicts. A Toolkit for Intervention. USAID/Office of Conflict Management and Mitigation.

lxxxviii. Vanacker, V., Linderman, M., Lupo, F., Flasse, S., \&Lambin, E. (2005). Impact of short-term rainfall fluctuation on interannual land cover change in sub-Saharan Africa. Global Ecology \& Biogeography, 14, 123-135.

lxxxix. Verdoodt, A., Mureithi, S.M. \& Van Ranst, E. (2010). Impacts of management and enclosure age on recovery of the herbaceous rangeland vegetation in semi-arid Kenya. Journal of Arid Environments, 74, 1066-1073.

xc. Vetter, S., Goqwana, W., Bond, W. \& Trollope, W. (2006). Effects on land tenure geology and topography on vegetation and soils of two grassland types in South Africa. African Journal of Range and Forage Science, 23(1): 13-27.

xci. Walker, R. \& Omar, H. (2002). Pastoralists under pressure. The politics of sedentarisation and marginalization in Wajir District, Northeast Kenya. A report for Oxfam GB. Nairobi: Oxfam GB.

xcii. Wasonga, V.O., Nyariki, D.M. \&Ngugi, R.K. (2011). Assessing socio-ecological change dynamics using local knowledge in the semi-arid lowlands of Baringo, Kenya. Environmental Research Journal, 5(1), 11-17.

xciii. Worku, A. (2016). Management of dry forests for socio-ecological resilience of pastoral and agro-pastoral communities in the dry zone of Ethiopia.Dresden: Doctoral Dissertation, TechnischeUniversität Dresden,.

xciv. Yacob, A. \&Catley, A. (2010). Mind the Gap. Commercialization, Livelihoods and Wealth Disparity in Pastoralist Areas in Ethiopia. A report for Tufts University and UKAid. Addis Ababa: Tufts University and UKAid.

xcv. Yacob, A. (2000). Pastoralism in Ethiopia: the issues of viability. Addis Ababa: Paper presented at the National Conference on Pastoral Development in Ethiopia.

xcvi. Yami, A. and Merkel, R.C. (2009). Management for Proper Range Use in Ethiopia. Technical Bulletin No.25. Addis Ababa: Ethiopian Sheep and Goat Productivity Improvement Program (ESGPIP). 